IJBPAS, December, Special Issue, 2021, 10(12): 387-394

ISSN: 2277-4998

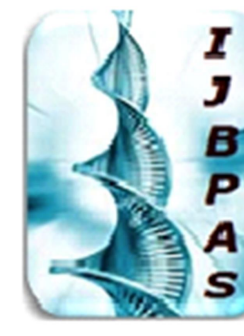

International Journal of Biology, Pharmacy

and Allied Sciences (IJBPAS)

'A Bridge Botuen Caboratory and QRader'

WwW.ijbpas.com

\title{
EVALUATION OF YASTIMADHUADI LIPBALM FOR ITS EFFECT ON OSTHASPHUTANA
}

\section{POOJA THAKUR ${ }^{1}$ AND VINAYKUMAR R KADIBAGIL ${ }^{2^{*}}$}

\section{1: UG Scholar}

2: Professor \& Head, Department of Rasashastra \& Bhaishajya Kalpana, Sri

Dharmasthala Manjunateshwara College of Ayurveda and Hospital, Hassan-573201

*Corresponding Author: Dr Vinaykumar R Kadibagil; E Mail: $\underline{\text { drvinaykadibagil@gmail.com }}$

Received $9^{\text {th }}$ May 2021; Revised $10^{\text {th }}$ July 2021; Accepted $29^{\text {th }}$ Aug. 2021; Available online $15^{\text {th }}$ Dec. 2021

\section{https://doi.org/10.31032/IJBPAS/2021/10.12.1034}

\begin{abstract}
Background: Beauty is of major concern in the present era and cosmetics plays a significant role in it. Natural and herbal cosmetics are mostly preferred nowadays due to its absence from numerous harmful chemicals.

This study focuses on the varnya, vranahara and kandughna properties of drugs viz yastimadhu (Glycyrrhiza glabra), manjistha (Rubia cordifolia), and raktachandana (Pterocarpus santalinus). These drugs were used in the form of balm using ghritha and siktha (Bee wax) as a base. It is a form of sthanik chikitsa to relieve sthanik lakshana. Lip balms are formulations applied onto lips to prevent drying and protect against adverse environmental factors.

Methods: Yastimadhuadi lip balm was prepared by using yastimadhu, manjistha and rakta chandana for kashaya and kalka. They were added to ghritha and sneha kalpana was done till sneha siddhi lakshana were obtained. 1 part of melted siktha was added to 5parts of filtered ghrita. After cooling honey was added $5 \%$ of total quantity of the product.

Result: Prepared lipbalm were given to 30 volunteers having osthasphutana and result was analyzed by questionnaire method.

Conclusion: From the feedback of volunteers, it was shown that yastimadhuadi lipbalm is beneficial in othasphutana. Thus, yastimadhuadi lipbalm can be prepared and used as herbal lipbalm.
\end{abstract}

Keywords: Yastimadhuadi lipbalm, osthasphutana, varnya, vranahara, kandhughana 


\section{INTRODUCTION:}

Cosmetic plays a significant role in today's life style ${ }^{1}$. Natural products have been used for folk medicine purposes throughout the world for thousands of years ${ }^{2}$. Herbal cosmetic products include various formulations.

Lip balms are formulations applied onto the lips to prevent drying and protect against adverse environmental factors $^{3}$. Numerous lip balms of chemical origin are currently available in the market are having side effects ${ }^{4}$.

Osthasphutana is cracking of lips associated with fissuring and peeling of skin of lips which gives pain and discomfort. Cracking leads to bleeding, soreness, inflammation and tenderness of the lips, and a burning sensation. Severely cracked lips that bleed and are not treated can become infected.

Many drugs like yastimadhu (Glycyrrhiza glabra), manjistha (Rubia cordifolia) and rakta chandana (Pterocarpus santalinus) are mentioned in ayurvedic classical having varnya, varnahara, kandugna properties.
So, using these drugs with addition ghrita and madhu lip balm will be prepared. These drugs don't have ushna, tikshna guna ${ }^{5,6,7}$ so can be used for all age groups.

Market available lip balms contain chemicals like petrolatum, Butylated hydroxy anisole, Butylated hydroxytoluene, parabens, phthalates, oxybenzene, salicylic acid, nickel, chromium. Research suggests that usage of these chemicals for long term may cause breast cancer. respiratory disorders, endocrine disorders, drying of lips etc ${ }^{8}$. Thus, there is a huge demand for herbal cosmetics. So, this study is undertaken to manufacture herbal lip balm.

\section{MATERIALS AND METHODS}

Yastimadhuadi lipbalm was prepared in department of Rasashastra and Bhaishajya Kalpana, SDM College of Ayurveda and Hospital, Hassan.

\section{Drug collection and authentication}

Drugs required were collected from SDM pharmacy and herbal drugs were authenticated from the experts of Dravya guna.

Table 1: Showing the ingredients of yastimadhuadi lip balm with proportion

\begin{tabular}{|c|c|c|c|c|}
\hline S. No. & Name of the drug & Latin/English name & Part used & Quantity \\
\hline 1. & Yastimadhu & Glycyrrhiza glabra & Root & 160 gm \\
\hline 2. & Manjistha & Rubia cordifolia & Root & $160 \mathrm{gm}$ \\
\hline 3. & Rakta Chandana & Pterocarpus santalinus & Heart wood & $160 \mathrm{gm}$ \\
\hline 4. & Siktha & Bee wax & - & $\mathbf{2 5 g}$ \\
\hline 5. & Madhu & Honey & - & $\mathbf{1 0 0 m l}$ \\
\hline 6. & Ghritha & Ghee & - & $\mathbf{2 4 0 m l}$ \\
\hline 7. & Water & Water & - & $7680 \mathrm{ml}$ \\
\hline
\end{tabular}




\section{Method of preparation of yastimadhuadi lipbalm}

1. All the ingredients were taken $160 \mathrm{gm}$ each and converted into coarse powder.

2. Kwatha was prepared by adding $7680 \mathrm{ml}$ of water (16 times) and reduced to $960 \mathrm{ml}\left(1 / 8^{\text {th }}\right)$.

3. Kwatha was filtered through clean cloth.

4. Fine powders of $7 \mathrm{gm}$ of each drug (total-27gm) was taken and to this powderwater was added to prepare kalka. Each $20 \mathrm{gm}$ and total $60 \mathrm{gm}$ of kalka was prepared.

5. $240 \mathrm{ml}$ of ghritha was taken. Thus, ratio of kalka: ghritha: Kashaya was 1(60gm):4(240ml):16(960ml)

6. Ghritha was processed with kalka and kashayatill sneha siddhi lakshana were observed. $240 \mathrm{ml}$ ghrita obtained as final sneha kalpana.

7. Various trials were done by varying the ratio of siktha and ghritha as $(1: 1,1: 3,1: 5,1: 6,1: 8)$

8. Among these trials, the $3^{\text {rd }}$ trial (1:5) was feasible considering the consistency.

9. 48 grams of siktha was melted and added into ghrita by filtering through the cloth resulting the product to 280 grams.

10. After cooling of the ghritha $5 \%$ of total product i.e., $14 \mathrm{gm}$ of honey was added and mixed.

11. This was packed into 30 bottles each of 8 grams.

12. A total of 15 volunteers were given with yastimadhuadi lip balm for application who suffered from osthasphutana.

Table 2: Proportion of siktha and ghritha

\begin{tabular}{|c|c|c|c|}
\hline S. No. & Ghritha & Siktha & Ratio \\
\hline 1 & $40 \mathrm{gm}$ & $40 \mathrm{gm}$ & $1: 1$ \\
\hline 2 & $40 \mathrm{gm}$ & $13.3 \mathrm{gm}$ & $1: 3$ \\
\hline 3 & $40 \mathrm{gm}$ & $8 \mathrm{gm}$ & $1: 5$ \\
\hline 4 & $40 \mathrm{gm}$ & $6.66 \mathrm{gm}$ & $1: 6$ \\
\hline 5 & $40 \mathrm{gm}$ & $5 \mathrm{gm}$ & $1: 8$ \\
\hline
\end{tabular}

Table 3: Showing the remark of obtained consistency with varied siktha proportion

\begin{tabular}{|c|c|c|}
\hline S. No. & Ratio of siktha and ghritha & Remark \\
\hline 1 & $1: 1$ & Very hard \\
\hline 2 & $1: 3$ & Soft but brittle \\
\hline 3 & $1: 5$ & Smooth and fine \\
\hline 4 & $1: 6$ & Very smooth easily smudgeable \\
\hline 5 & $1: 8$ & Liquid consistency \\
\hline
\end{tabular}

\section{Selection of patients}

The study was conducted in 30 volunteers having osthasphutna. Each were provided with 8 grams pack of each. They applied it 3 times per day and were asked to submit their feedback based on their experience. 


\section{Selection criteria}

Individuals of either sex within the age group of 15 to 50 years suffering from osthasphutana were selected.

\section{Exclusion criteria}

- Individuals below 15 years and above 50 years.

- Patient associated with other major systemic or psychiatric diseases.

\section{Observation and results}

To evaluate efficacy of yastimadhuadi lipbalm, preliminary clinical study was conducted with permission of institutional ethical committee (SDM/IEC/73/2019). Prepared yastimadhuadi lipbalm was provided to 30 volunteers for external application on lips.

\section{Result of yastimadhuadi lipbalm}

1. Out of 30 volunteers $76.7 \%$ do not feel the sense of dryness at all after using yastimadhuadi lip balm.
2. $80 \%$ reported complete absence of fissuring / cracking.

3. $66.7 \%$ reported absence of scaling of lips.

4. $96.7 \%$ reported absence of any kind of irritation of lips.

5. $53.3 \%$ mentioned markedly improvement in smoothness whereas $\quad 40 \% \quad$ mentioned improvement and $\quad 6.7 \%$ mentioned slight improvement.

6. $43.3 \%$ mentioned marked improvement, $36.6 \%$ mentioned improvement whereas $16.7 \%$ mentioned slight improvement in visual grading of condition of lips.

7. $93.3 \%$ claimed as no necessity of using any other moisturizing agent on lips after use of yastimadhuadi lip balm.

Result of analytical tests for yastimadhuadi lip balm

\begin{tabular}{|c|c|c|}
\hline S. No. & Test name & Result \\
\hline 1 & Spread ability & Intermediate \\
\hline 2 & $\mathbf{p H}$ & $\mathbf{6 . 9 3}$ \\
\hline 3 & Total solid content & $\mathbf{7 8 ~ b r i x}$ \\
\hline 4 & Refractive index & $\mathbf{1 . 4 7}$ \\
\hline 5 & Loss on drying & $\mathbf{1 \%}$ \\
\hline
\end{tabular}



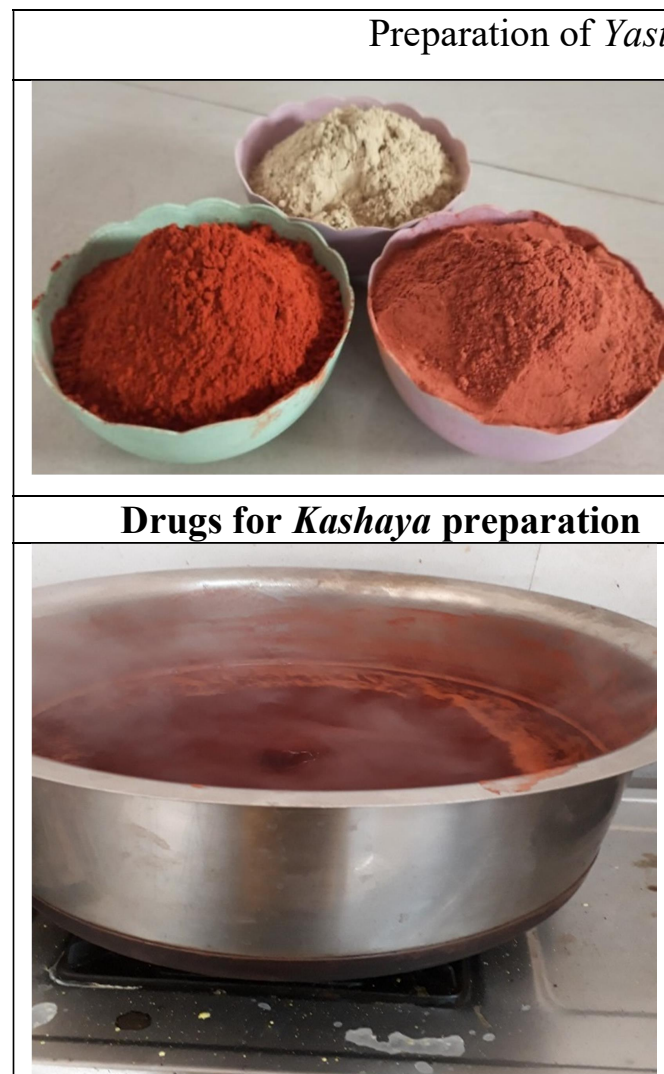

Kashaya reduction

\section{Kalka prepared}

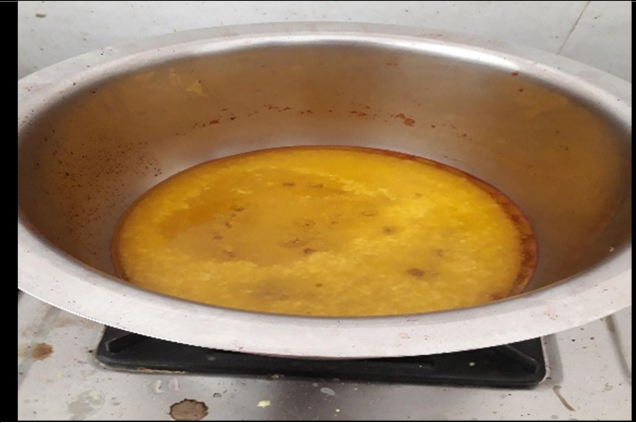

Ghritha added for sneha kalpana
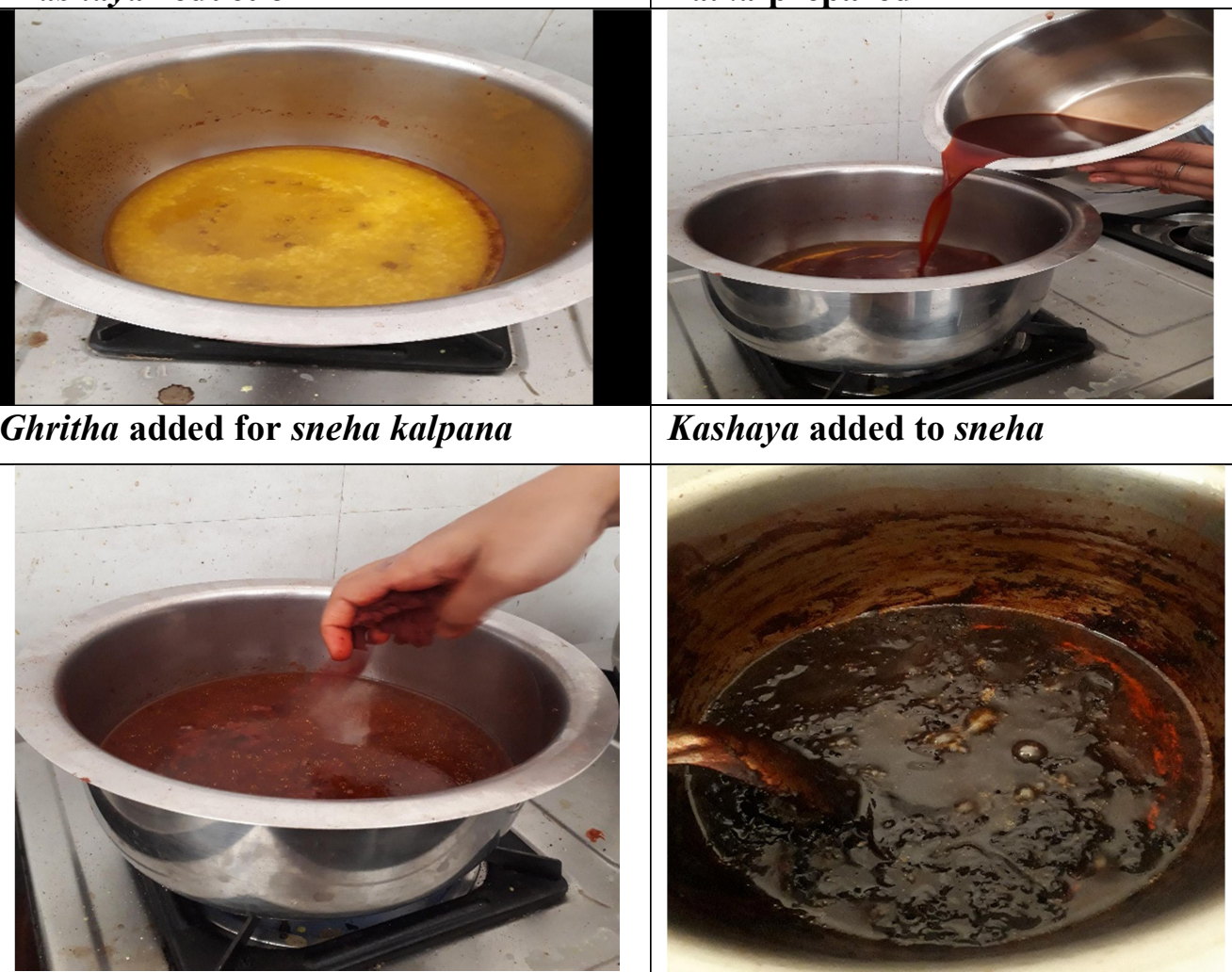

Kashaya added to sneha

Addition of kalka to the sneha and Siddhi lakshana of the sneha kashaya

\section{kalpana}




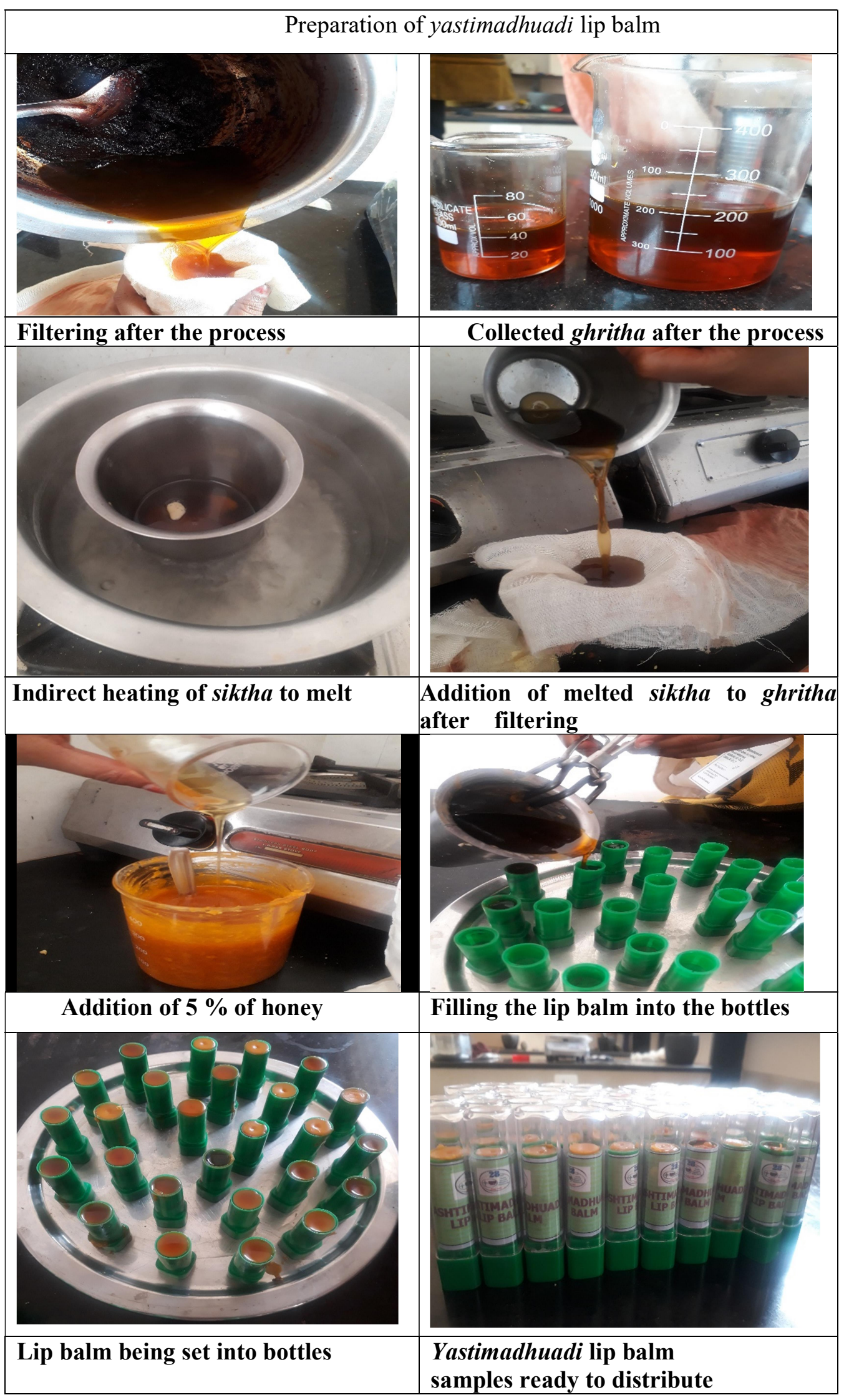




\section{DISCUSSION:}

Honey helps to enhance the moisture content of the lip balm and lighten up the dark lips. Honey has antioxidants along with bleaching action that help to remove the darkness and repair daily UV damage of the lip skin. Essential fatty acids of ghee help in conditioning and nourishing of dry, chapped lips. Beeswax is a natural emulsifier often used in cosmetics, particularly lip balm. It is very creaming with pleasant smell and will help to protect the lips from the harmful rays of the sun'. Based on texture, formulations with ratios of siktha to ghritha, 1:2, 1:3 have higher values of hardness as compared to the other ratios. The visual remark by bare eyes shows that the data for ratios of siktha to ghritha, 1:2, 1:3 seen to have very thick semi-solid texture. In contrast, the other ratios 1:5, 1:6, 1:8, have a cream-like touch due to the high amount of ghritha used and make the lip balm feel a bit hefty on the lips. It can be inferred that the higher amount of beeswax in the formulation, the higher the hardness value is. These situations occur due to the addition of herbal drugs powder to the formulation, make the formulation harder or softer and affect the value of lip balm hardness.

Lip balm was found to have Intermediate spreadability- Uniform; leaves few fragments; appropriate application; little deformation of the lip balm. $\mathrm{pH}$ of lip balm was near to neutral $\mathrm{pH}$ i.e.; 6.9 this would not cause any irritation to lips.

Osthasphutana is one of commonest problem nowadays. Adverse climatic conditions, any sort of infection or dehydration are commonest cause for it. Balm is a form of lepa which pacifies vitiated dosha and cures the condition. Yastimadhuadi lipbalm consists of drugs having high potency for vranahara and varnya action which relieves cracks and restores natural pigmentation of lips.

\section{CONCLUSION}

Honey used in the formulation was helpful in enhancement the moisture content of the lip balm. Drugs like manjista, rakta chandana were given colour along with their therapeutical properties. Ghritha was helpful in maintaining slipperiness of lip balm. Bee wax was helped in thickness of lip balm. The results shown that yastimadhuadi lip balm was effective in osthasphutana property. Analyzing the volunteer's feedback, it can be concluded that lip balm formulation was beneficial for overall problems of lips. So, yastimadhuadi lip balm can be prepared which will continue the usage of traditional practice.

Source of support and Acknowledgement

Rajiv Gandhi University of Health Sciences, Bengaluru Karnataka. Short term 
research grant for undergraduate students

with project name - Evaluation of efficacy

of yastimadhuadi lipbalm on osthasphutana and project code - UG20AYU071

\section{REFERENCES}

[1] Kadu M, Vishwasrao S, Singh S. Review on natural lip balm. International Journal of Research in Cosmetic Science. 2015;5(1):1-7.

[2] Shreevalli p, Vinaykumar R Kadibagil. Comparative analgesic effect of traditional shuntyadi yoga lepa and its neo formulation as Balm on Shirashula. International journal of ayurvedic medicine.2021.12 (1):120-123.

[3] Fernandes AR, Dario MF, Pinto CA, Kaneko TM, Baby AR, Velasco MV. Stability evaluation of organic Lip Balm. Brazilian Journal of Pharmaceutical Sciences. 2013; 49:2939.

[4] Azmin SN, Jaine NI, Nor MS. Physicochemical and sensory evaluations of moisturising lip balm using natural pigment from Beta vulgaris. Cogent Engineering. 2020 Jan 1;7(1):1788297.

[5] Prakash L Hegde, Harini A, Yastimadhu, A textbook of Dravya Guna Vigyana Vol 2, Page no. 903

[6] Prakash L Hegde, Harini A, Manjistha, A textbook of Dravya Guna Vigyana Vol 2, Page no. 578

[7] Prakash L Hegde, Harini A, Raktachandana, A textbook of Dravya Guna Vigyana Vol 2, Page no. 225

[8] Yusof AA, Ajit AB, Sulaiman AZ, Naila A. Production of lip balm from stingless bee honey. 2018;1(1);57-72.

[9] Vinodkumar JA, Chandrahar GK, Pradip DP. Formulation and Evaluation of Organic Lip Balm. Indo American Journal of Pharmaceutical Research. 2019;9(4):1994-7. 